\title{
Quality of Life of Schizophrenic Patients with or without Depot Neuroleptics
}

\section{ABSTRACT}

Introduction: Schizophrenia is a chronic mental illness that negatively affects the quality of life of the patient and his family. Primary therapy in the treatment of schizophrenia is antipsychotics.

Aims of the study: The aim of this study was to compare the quality of life of schizophrenic patients treated with depot neuroleptics preparations and patients without depot neuroleptics.

Patientes and Methods: The sample size included 64 patients aged 18-65 years divided into two groups: patients treated with depot neuroleptic preparations and the control group, patients not treated with depot neuroleptics. For the investigation we used history and socio-demographic data, body weight, blood pressure, as well as quality of life questionnaire [a combination of Lancashire and Mansa questionnaire) and short scale for psychiatric evaluation (BPRS)

Results: The average age of the examinees was $44.19 \pm 7.785$ years (experimental group: $43.31 \pm 6.879$ and control $45.06 \pm 8.617$ years). Regarding the frequent changes in mood, there were no statistically significant differences between the groups, $\mathrm{Hi}=0000, \mathrm{p}<0.05$. A statistically significant difference between the groups was found in the presence of hallucinations ( $c 2=8.400$, $d f=3, p=0.038$ ),

Conclusion: It was found that the quality of life of patients treated for schizophrenia does not significantly differ, regardless of whether depot preparations are used or not; this finding is in accordance with the reports made by other authors.

Keywords: schizophrenia, quality of life, neuroleptics, depot preparations

DOI: $10.7251 / S M D E N 1501060 S$

(Scr Med 2015:46:60-65)
Ivana Simić Medojević1, Marija BurgićRadmanović ${ }^{2}$

Center for Mental Health, $\mathrm{PHI}$ "Health Center" Gradiska1, Clinic for Psychiatry, University Hospital Clinical Center, Banja Luka2

\section{Contact address:}

Ivana Simić Medojević

Vrbaski put br 16

7800 o Banja Luka

Tel: +38765917403

E-mail: cmzgradiska@gmail.com
Submitted: October 12th, 2014 Accepted: January 24th, 2015

\section{Introduction}

Schizophrenia is a chronic mental illness with a prevalence of about one percent. ${ }^{1}$

Schizophrenia occurs earlier in males than in females 2,3 Most frequently it occurs in males between 15 and 24 years, while in females between 25 and 34 years. ${ }^{4,5}$ For the development of schizophrenia, biological factors, social factors and factors of individual life experience are of great importance. ${ }^{6,7}$ The primary symptoms of schizophrenia fall into disorders of the association of thought, affect disorder, ambivalence and autism (four A syndrome, by 
Bleuler).$^{8,9}$ Schizophrenia is characterized by an altered opinion in form and content. ${ }^{10-15}$

Primary therapy in the treatment of schizophrenia represents pharmacotherapy, with antipsychotics playing a significant role. ${ }^{16,17}$

The World Health Organization (WHO), under the quality of life, implies the perception of individuals on their position in life, in the context of the culture and value systems in which they live and in relation to their goals, expectations, standards and concerns about their environment. ${ }^{18-20}$ Research on the quality of life of mentally ill people appeared at the beginning of the nineties, followed by a plethora of studies on quality of life of patients with somatic symptoms. ${ }^{21-23}$ There is no doubt that the assessment of the quality of life of psychiatric patients is in relation to the objective social factors, physical health, emotional, family and cultural factors. ${ }^{24,25}$

\section{Aim of the study}

The aim of this study is to compare the quality of life of schizophrenic patients treated with depot neuroleptics and without depot neuroleptics.

\section{Patients and Methods}

The study included patients treated in the period from December, 2011 to September, 2012, at the Center for Mental Health, PHI "Health Center" Gradiska. The investigation was conducted in compliance with the Declaration of Helsinki on medical research and the principles of good scientific practice. Initially, 67 patients were selected for the study, but only 64 were further included in the study, aged 18-60 years, out of which 36 were female subjects (56.3\%) and 28 male (43.7\%). Patients whose intellectual abilities were at the level of light mental retardation were excluded from the study.

Experimental group consisted of patients suffering from schizophrenia, treated with depot neuroleptics and with or without additional oral therapy $(n=32)$. The control group consisted of patients suffering from schizophrenia and receiving oral therapy exclusively $(n=32)$. Informed consent was obtained from all study subjects. Based on medical history, socio-demographic data, and medical records assessment, we obtained data on the age, marital and employment status, level of education and the presence of somatic diseases in patients. Determination of body weight was done using calibrated scales and recorded values were expressed in $\mathrm{kg}$; body height was determined using stadiometer and recorded values were expressed in $\mathrm{cm}$. Quality of Life Questionnaire and BPRS were filled by the examiners after examinees provided their answers to the questions.
Statistical analysis was performed using SPSS (Statistical Package for the Social Sciences), version 20, as the analytical statistical tool.

Data were analyzed using descriptive statistics. $\chi^{2}$-test of independence was used to determine the relationship between two categorical variables.

\section{Results}

The results of data analysis showed that the average age of the examinees was $44.19 \pm 7.785$ (experimental group: $43.31 \pm 6.879$ and control: $45.06 \pm 8.617$ years). Age of the examinees in both groups is shown in Table 1.

Table 1. Age of examinees

\begin{tabular}{lr|c|c|c|c|c|c|c}
\hline Examinees group N & Min. & Max. & $\begin{array}{c}\text { Ran- } \\
\text { ge }\end{array}$ & $\begin{array}{c}\text { Me- } \\
\text { dian }\end{array}$ & Mean & $\begin{array}{l}\text { Std. } \\
\text { Dev. }\end{array}$ & $\begin{array}{c}\text { CV } \\
(\%)\end{array}$ \\
\hline $\begin{array}{l}\text { Experimental } \\
\text { group }\end{array}$ & 32 & 28 & 52 & 24 & 46.00 & 43.31 & 6.879 & 15.88 \\
\hline $\begin{array}{l}\text { Control group } \\
\text { Total }\end{array}$ & 28 & 60 & 32 & 48.00 & 45.06 & 8.617 & 19.12 \\
\hline
\end{tabular}

$\mathrm{N}=$ number of subjects $\mathrm{Min}=$ age of the youngest subject Max= age of the oldest subject Range $=$, average age of the subject Median= mediana, Mean= arithmetic mean Std. Dev.= Standard deviation CV (\%) = coefficient of variation .

Using a Man-Whitney U test of rank to analyze the data on arterial pressure, no significant difference was found in systolic arterial pressure values between the experimental $(\mathrm{Md}=122.5 \mathrm{O}, \mathrm{n}=32)$ and control $(\mathrm{Md}=122.5 \mathrm{O}, \mathrm{n}=32)$ group, $\mathrm{U}=440$ 000, $\mathrm{z}=-0977, \mathrm{p}=0328, \mathrm{r}=0.12$, as well as in diastolic arterial pressure between the experimental $(\mathrm{Md}=82.5 \mathrm{O}, \mathrm{n}=32)$ and control $(\mathrm{Md}=87.5 \mathrm{O}, \mathrm{n}=32)$ group, $\mathrm{U}=487$ 000, $\mathrm{z}=-0341, \mathrm{p}=0.733, \mathrm{r}=0.04$. Results showing the level of satisfaction in quality of life: housing, friends, visits to cultural events and religiosity are presented in Table 2.

Using the Chi-square test of independence for analysis, data showed that there were no statistically significant differences in both groups compared to inflammatory therapy $\left(\chi^{2}=1570, \mathrm{SS}=2, \mathrm{p}=0.456\right)$, as well as the presence of frequent mood changes $\left(\chi^{2}\right.$ $=0077, \mathrm{SS}=1, \mathrm{p}=0.781$ ); while the examination of hallucinations showed statistically significant difference between two groups $\left(\chi^{2}=8.400, \mathrm{df}=3, \mathrm{p}=0.038\right)$. Neuroleptics in relation to the number of patients are presented in Table 3. 
Table 2. $\chi^{2}$ - test and the level of statistically significant differences in housing, satisfaction with friends, visits to cultural events and religiosity between the experimental and control group.

\section{Characteristic}

Experimental group Control group Total

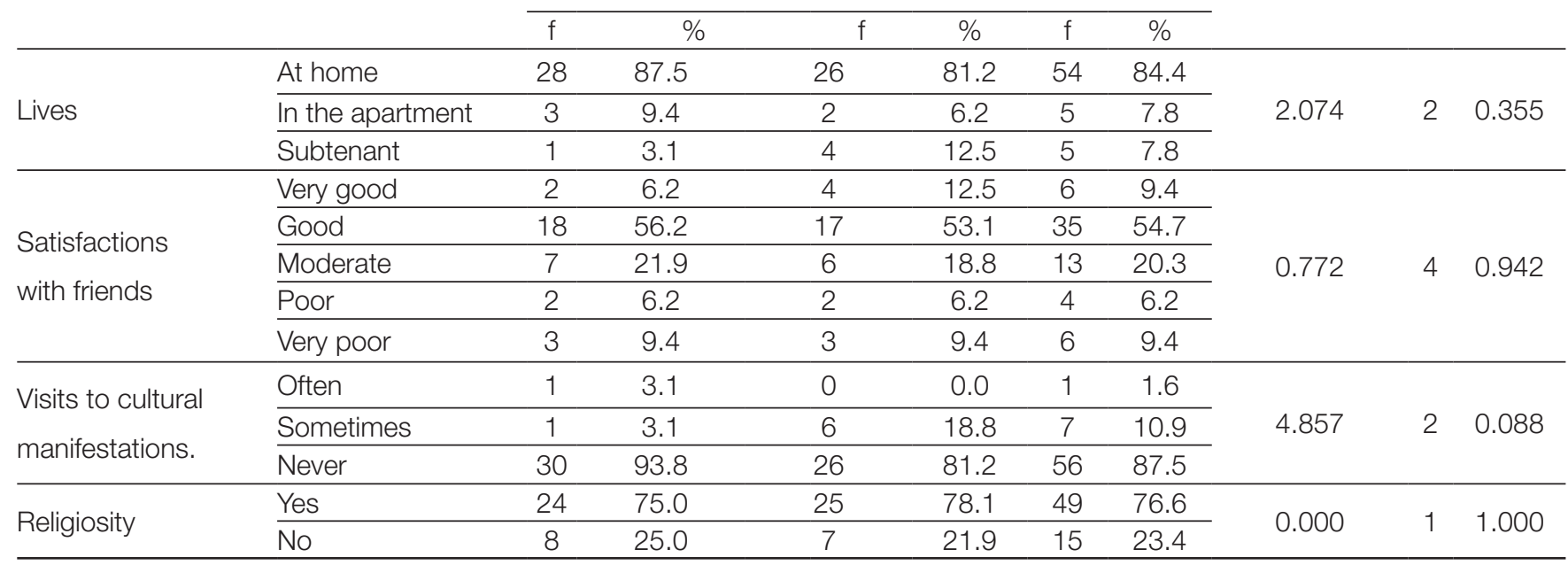

$f=$ number of patients in the experimental group, the control group and the total number of patients, $S S=b$, degree of freedom, NSZ = level of statistical significance (p)

Table 3. Neuroleptics in relation to the namber of patients

\begin{tabular}{lcc}
\hline Neuroleptics & $\begin{array}{c}\text { depot forms } \\
\text { number of patients }\end{array}$ & $\begin{array}{c}\text { tablets } \\
\text { number of patients }\end{array}$ \\
\hline Flufenazin & 27 & 4 \\
\hline Haloperidol & 6 & 5 \\
\hline Risperidon & 3 & 12 \\
\hline Klozapin & - & 15 \\
\hline Prasine & - & 9 \\
\hline
\end{tabular}

The presence of disorientation was not found in the study groups.

\section{Discussion}

Measures of the quality of life of schizophrenic patients are used for different purposes. In the first place it serves the purpose to assess the performance of methods of treatment, so called application of new medications, including the widely conceived programs for the prevention of mental disorders. ${ }^{21-27}$

Research studies of Salokangas et al. showed that the quality of life of schizophrenic patients in Finland was higher in those subjects who lived in good marital or partnership relationships. ${ }^{28,29}$ The quality of life of schizophrenic patients was also examined by Holzinger et al., with participation of 605 psychiatrists in Germany, where it was shown that the highest ranked aspect of quality of life was the patient's satisfaction, i.e. social interaction, contacts and the acceptance by the people in their immediate family environment, followed by lack of symptoms and the ability to work..$^{30}$ However, the study including schizophrenic patients in Nigeria showed that their quality of life was more dependent on marital status and employment, meaning that married and employed were more satisfied with the quality of life. ${ }^{31,32}$ Similarly, the studies on schizophrenic patients from different cultural backgrounds, such as China, showed higher scores of quality of life achieved by employed persons living in families who were religious, and older examinees with higher incomes, but the differences were not significant. ${ }^{33-34}$ In contrast, our research did not show significant disparities in the quality of life of schizophrenic patients, in accordance with research conducted by Kuga A. et al. in Japan, who showed that none of the socio-demographic or objective variables affected the assessment of the quality of life of schizophrenic patients. ${ }^{35}$

Regarding the treatment of schizophrenic patients, haloperidol decanoate may have a significant effect on improvement of the symptoms and behaviors in comparison to placebo, but the data to confirm this theory are extremely rare. ${ }^{36-40}$ There are no visible differences between haloperidol administered in depot form or orally. For those who need this medicine and who wish to use it, the method on which the medicine enters the body is a matter of personal choice and clinical assessment. ${ }^{41-45}$ Since there are clear differences between haloperidol decanoate 
and other depots, the choice of depot medication could also be a matter of personal judgment and the patient's attitude about the form that is more suitable for use. ${ }^{46-}$ ${ }^{49}$ Fluphenazine decanoate does not reduce relapse more than orally administered neuroleptics or other depot antipsychotics. ${ }^{50-54}$ The research showed that there was small advantage of depot-forms compared to the same medicine taken orally, in terms of compatibility. However, this is not broadly applicable in everyday clinical practice. .5 Following two groups of schizophrenic patients after discharge from a psychiatric hospital during period of one year, where one group was administered oral therapy and the other a depot formulation, it was found that patients on oral therapy had higher rates of re-hospitalization and their quality of life was not better than in patients on depot medication..$^{56}$ These findings were partially in agreement with our study results that showed no difference in the quality of life of schizophrenic patients on depot preparation and those taking oral agents.

\section{Conclusion}

On the basis of the conducted research we can conclude that the results of our study are in agreement with the results of other studies. The quality of life of schizophrenic patients treated with or without depot preparations was mainly the same, with small deviations. There were no statistically significant differences between two groups based on gender, age structure, education, employment, body weight, and body height. A statistically significant difference was determined in the presence of hallucinations, which were more frequent in patients treated with depot preparations neuroleptics, in comparison to subjects without depot in therapy. Disorientation was not present in either group of examinees. These results may contribute to the treatment and improvement of quality of life of the patients suffering from this disease.

\section{References}

1. Marić J. Psychiatry. Beograd, 2004;122-191

2. Kecmanović D. Psychiatry. Beograd- Zagreb, 1987;813-911

3. Prince JD. Ethnicit and life guality of recently dischargen in-patients with schizoprenia. Am J Orthopsychiatry 2006;76 (2):2025 .

4. Hewitt J.Critical evaluation of the of research tools in evaulating guality of life for people with schizofrenia. Int J Ment Healt Nurs 2007;16(1):2-14.

5. Martin CR Allan R. Factor structure of the Schizophrenia Quality of Life Scale Revisin 4(SQLS-R4). Psychol Health Med 2007;12(2):126-34

6. Sartorius, N. Latrogenis stigmus of mental illness. BMO 2002;324,1470-1471

7. The ICD Classification of Mental and Behavioral Disorders, World Health Organization, Geneva, 1992;78-92

8. Kaličanin P. Psychiatry . Beograd, 2002;583-618

9. Milovanović D, Milovanović S. Clinical psychopharmacology. Beograd, 2005;173-211
10. Kučukalić A, Dzubur-Kulenović A, Bravo- Mehmedbašić A. Instructions for treating schizophrenia Sarajevo,2006; 67-78

11. Opalić P. The Patients theory of illness treatment and medicament. In Čović B, editor. The man and the medicament Belgrade:institute for mental Health; 2004.p 23-34 (Serbian)

12. Scott J, \& Dixon L. Psychologic interventions for shizofrenia. Schizofrenia Bulletin 1995; 21,621-630

13. BengtssonTop A, Hansson L. Quantitative and qualitative aspects of the social aspects of the social network in shizophrenic patients livinh in community. Relationship to socio-demographic and clinical factors and subjektive quality of life. Int J Soc Psychiatry 2001;47(3):67-77

14. Eack SM, Newhill CE, Anderson CM, Rotondi AJ. Quality of life for persons living with shizofrenia:more than just symptoms. Psychiatr Rehabil J 2007;30(3):219-22

15. Lehman AF. Measures of quality of life among persons with severe and persistent mental disorders. Soc Psychiatry Psychiatr Epidemiol $1996 ; 31(2): 78-88$

16. Trompenars FJ, Masthoff ED, Van heck GI, Hodiamont PP, De vries J. Relationships between demographic variables and quality of life in a population of Dutch adult psychiatric outpatinets. Soc psychiatric Psychiatr Epidemiol 2005;40 (7)588-94

17. Miljković S, Vukić D, Trajanović Lj. Quality of life in mental disorders. Nis: Society behavioral theory and practice in 2004; 52-63

18. Evans S, Huxley P, Priebe S.A comparison of the quality of life of severely mentaly ill people in UK and German samples. Int J Soc Psychiatry 2000;46 (1):47-56

19. Pušičić V, Mihajlović G, Popović-Deušić S, Đukić-Dejanović S, Ignjatović-Ristić D. Quality of life of psychotic patients: clinical significance and scale of assessment. Engrami 2005; 27 (1-2): 7-14

20. Faulkner G, Cohn T, Remington G, Irving H. Bodymass index waist circumference and quality of life in individuals with shizofrenia. Shizophr Res 2007;90 (1-3):174-8

21. The World Health Organization Quality of Life Assessment (WHOQOL): development and general psychometric properties. Soc Sci Med 1998;46 (12):1569-85

22. Lauer G. Results og guality of life research in chronic psychiatric patients. Psychiatr Prax 1993;20(3):88-90 (German)

23. Opalić P, Nikolić S. Quality assessment of schizophrenic patients, Belgrade. Medical examination in 2008; 61-83

24. Salize HJ. Guality of life social deprivation and mental disordersis there an association in populations at risk? Psychiatr Prax 2006;33 (7):323-9 (German)

25. Kirson NY Weiden PJ, Yermacov S,et al. Efficacy and effectiveness of depot versus oral antipsychotics in schizofrenia:synthesizing results across different resarch designs. $J$ clin Psychiatry 2013;74(6):568-575

26. Leucht S, Tardy M, Komossa K, et al. Antipsychosis drugs versus placebo for relapse prevention in schizofrena: a systematic review and meta-anlysis. Lancet 2012;379 (9831) 2063-2071

27. Barnes TR. Evidence-based guidelines for the phrmacological treatment of schizofrena: recommendations from the british Association for Psyghopharmacology. J Psychopharmacol 2011;25(5):567-620

28.Salokanges RK, Honkomen T, Stergard E, Koivito AM. Subjektive life satisfaction and living situatins of persons in Finlanda with long -teim schizofhrenia.Psychiatr Serv 2006;57(3):373-81 
29. Salokangas RK, Honkonen T, Stengard E, Koivisto AM To be or not to be married-that is the guestion of guality o life in men with schizofrenia. Soc Psychiatry Psychiatr Epidemiol 2001;36(8):38190

30. Holzinger A, Angermeyer MC, Matschinger H. Ouality of life for schizophrenic patients-that is... Results of survey of psychiatrits. Psychiatr Prax 1997;24(2):61-4 (German)

31. Mortimer AM, Al-Agib AO. Guality of life in schizofrenia on conventional versus atypical antipsychotic medication: a comparative cross-sectional study.Int J Soc Psychiatry 2007;53(2) 99-107

32. Llorca PM, Miadi-Fargier H, Lançon C, Jasso Mosqueda G, Casadebaig F, Philippe A, Guillon $\mathrm{P}$, Mehnert A, Omnès LF, Chicoye A, Durand-Zaleski I. Cost-effectiveness analysis of schizophrenic patient care settings: imact of an atypical antipsychotic uder longacting injection formulation, Soc Psychiatry Psychiatr Epidemiol 2005; 67-81

33. Chan SW, Hsing PC, Thompson DR, Chen SC, Hwu HG. Healthrelated guality of life of Chinese people with schizophrenia in Hong Kong and Taipei: a cross-sectional analysis. Res Nurs Health 2007;30(3):261-9.

34.Taniguchi T, Sumitani S, Aono M, Iga J, Kinouchi S, Aki H. Effect ofantipsychotic replacement withguetiapine on the symptoms and guality of life of schizofrenic patients with extrapiramidal synptoms.hum Psychopharmacol 2006; 21(7): 439-45 32.

35. Kugo A, Terada S, Ishiza H, Taleda T, Soto S, Habora T. Guality of life for patients with schizoprenia ina a Japanese psychiatric hospital. Psychiatry Res 2006;144 (1):49-56

36. Solokhina T. Guality of life reletives of the mentlly ill as an integral index of psychiatric care guality. Quality of life Research 1997;6:724 (abstract)

37. Kavess- Masfety Y, Xavier M, Moreno Kastner B, Suchocka A, Sevilla-Dedien C, Dabius J. et al. Schizofrenia and gualityof life:a one-year follow-up in four EU countries. BNC Psychiaty 2006;6:39

38. Hasan A, Falkai P,Worbock T,et al.World Federation of Societes of Biological Psychiatry(WFSBP) Guidelines for Biological Treatment of schizofrenia and the menagement of treatment resistence. World J Biol Psychiatry 2012;13(5);318-378

39. Zhornitsky S, Stip E, Oral versus long-akting injectable anipsychotics in the treatment of schizofrenia and special populatins at risk for treatment nonadherence:a systematic review. Schizophr Res Treatment 2012;2012:407171

40.Offord S,Wong B,Mirski D, Baker RA,Lin J.Healtcare resource usage of schizofrenia patients initiating long-acting injectable antipsychotics vs oral. Jmed Econ 2013;16(2):231-239

41. Schmidt K, Staupendahl A, Vollmoeller W. Guality of life of schizophrenic psychiatric out patients as a criterion for treatment planning in psychiatric intitutins. Int $\mathrm{J}$ SOC Psychiatry 2004;50(3):262-73

42.Bamiso Mekanjuola A, Ademola Adeponle B, Ayodele Obrmbe O. A comporison of guality of life in schizofhrenia and afective disorder patients in a Nigerian tertiary hospital. Transkult Psychiatry 2007;44 (1):65-78
43. Fusar-Poli P, Kempton MJ, Rosenheck RA. Efficacy and safety of second-genaration long-action injections in schizofrenia:a metanalysis of randomized-controlled trials. Int clin Pssychopharmacol 2013;28 (2):57-66

44. Kane JM, Kishimoto T, Correll CU. Assessing the comporative effectiveness of long-acting injectable vs oral antipsychotic medications on the prevention of relapse provides a case study in comparative effectiveness research in psychiatry. J clin Epidemiol 2013;66 (Suppl 8):S37-S41

45. Bartzokis G, Lu PH, Raven EP, et al.Impact on intracortical myelination trajectory of long acting injection versus oral risperidone in first-episode schizofrenia. Schizophr Res 2012;140(1-3):122128

46.Taylor M, Ng KY, Should long-acting (depot) antipsychotics be used in early schizofrenia?A sistematic review. Aust N Z J Psychiatry 2013;47 (7):624-630

47. Sanza LA, Continho ES. Associated factors to guality of life pf patients with schizophrenia, living in community in Rio de Janeiro, Brazil, Soc Psychiatry Psychiatr Epidemiol 2006;41(1):47-56

48. Lin J, Wong B, Offord S, mirski D. Healthcare cost reductions associated with the use of LAI formulations of antipsychotics medications versus oral among patients with schizofrenia. J Behav Healt Serv Res 2013;40 (3):355-366

49. Bera R, Offord S, Zubek D, et al.Impact on healtcare resource usage and cost among Medicaid-insured schizofrenia patients after initation of treatment with long-acting injectable antipsychotics. J Med Econ 2013;16 (4):522-528

50. Furiak NM, Gahn JC,Klein RW, Camper SB, Summers KH. Estimated economic benefits from low-freguency adminastration of atipical antispychotocs in treatment of schizofrenia: a decision model. Ann Gen Psychiatry 2012;11(1):29

51. Rader- Wanner UU, Oliver JP, Priebe S. Does guality of life differ in schizophrenic women and men? An empirical study. Int J Soc Psychiatry 1997;43(2):129-43

52. Osborne RH, Dalton a, Hertel J,Schrover R, Smith DK, Healtrelated guality of life advantage og long-acting injectable antypsihotics treatment for schizofrenia: atime trade-off study. Healt Quality Life Outcomes 2012;10:35

53. Rossi G, Frediani s, Rossi R, Rossi A, long-acting antipsychotics drugs for the treatment of schizofrenia:use in daily practice from naturalistic observations. BMC Psychiatry 2012;12:122

54.McCabe R, Bullenkamp J, Hansson L, et al. Thee terapeutic relationship and adherence to antypsichotics medication in schizofrenia. PloS One.2012;7(4):e3608o

55. Dibonaventura M, Gabriel s, Dupclay L, Gupta S, Kim E. A patient perspective of the impact of medication side effects on adherence:results of a cross-sectional nationwide survey of patients with schizofrenia. BMC Psychiatry 2012;12:20

56. Becker M, Diamond R, Sainfort F. A new patient focused index for measuring guality of life in persons with severe and persistens mental illness. Qual Life Res1993;2 (4):239-5 


\section{Kvalitet života shizofrenih pacijenata sa i bez depo preparata neuroleptika}

\section{SAŽETAK}

Uvod: Shizofrenija je hronično mentalno oboljenje koje negativno utiče na kvalitet života, pacijenta i njegove porodice. Osnovnu terapiju u liječenju shizofrenije predstavljaju antipsihotici.

\section{Cilj istraživanja:}

Cilj istraživanja je bio da se uporedi kvalitet života shizofrenih pacijenata koji se liječe depo preparatima neuroleptika i pacijenata bez depo preparata neuroleptika.

Ispitanici i metode: Uzorak čine 64 pacijenta uzrasta od 18 do 65 godina koji su podijeljeni u dvije grupe: grupu pacijenata liječenjih depo preparatima neuroleptika i kontrolnu grupu bez depo preparata neuroleptika. U istraživanju su korišteni anamnestički i sociodemografski podaci, tjelesna težina, arterijski krvni pritisak te upitnik o kvaliteti života (kombinacija Lankaširskog i Mansa upitnika) i kratka skala za psihijatrijsku procjenu (BPRS).

Rezultati: Prosječna starost svih ispitanika je bila 44.19 \pm 7.785 godina (ekperimentanla grupa: $43.31 \pm 6.879$ i kontrolna: 45.06 \pm 8.617 godine). Nije bilo statistički značajne razlike između ispitivanih grupa o prisustvu čestog neraspoloženja $\mathrm{Hi}=0000$, $p>0.05$. Utvrđena je statistički značajna razlika između ispitivanih grupa u postojanju halucinacija (c2 $=8.400, S S=3, p=0.038)$.

Zaključak: Utvrđeno je da nema bitnije razlike u kvaliteti života pacijenata koji se liječe od shizofrenije, bez obzira da li se koriste depo preparati ili ne, što je u saglasnosti sa rezultatima drugih autora.

Ključne riječi: shizofrenija, kvalitet života, neuroleptici, depo preparati 